\title{
Penerapan Model Discovery Learning Berbantuan Media Flipbooks dalam Pembelajaran Fisika untuk Melatih Keterampilan Metakognisi Siswa SMAN 10 Gowa
}

\author{
Nurfadillah $^{1)^{*}}$, Windy Cahyana ${ }^{1)}$, Dian Pramana Putra ${ }^{1)}$ \\ ${ }^{1)}$ Program Studi Pendidikan Fisika, FKIP Universitas Muhammadiyah Makassar \\ *nurfadillahfis20@gmail.com
}

\begin{abstract}
Abstrak: Penelitian ini bertujuan untuk mengetahui Penerapan model discovery learning berbantuan media flipbooks dalam pembelajaran fisika untuk melatih keterampilan metakognisi siswa SMAN 10 Gowa tahun Ajaran 2020/2021. Jenis penelitian ini adalah penelitian pra-eksperimen (Pre-Experimental Design). Desain penelitian yang digunakan adalah One-Group Pretest-Posttest Design. Pada desain ini, sebelum diberi perlakuan, maka terlebih dahulu sampel diberikan tes awal (pretest) dan di akhir pembelajaran sampel diberi tes akhir (posttest. Sampel yang digunakan dalam penelitian ini yaitu kelas X MIPA 1 di SMA Negeri 10 Gowa yang berjumlah 34 peserta didik. Pengambilan sampel dilakukan dengan menggunakan teknik purposive sampling. Instrument Dalam penelitian ini menggunakan tes keterampilan metakognisi . Data yang diperoleh diolah dengan mengggunakan teknik analisis deskriptif dan analisis inferensial. Hasil penelitian Setelah dilakukan pengujian data skor pretest dan posttest membuktikan bahwa data terdistribusi normal , selanjutnya berdasarkan hasil pengujian hipotesis penelitian dengan menggunakan uji-t, untuk nilai thitung sebesar 8,9424 sedangkan ttabel sebesar 2,036. Hasil yang diperoleh menunjukkan bahwa thitung > ttabel yang artinya $\mathrm{HO}$ ditolak dan $\mathrm{H} 1$ diterima, hal ini menunjukkan bahwa terdapat peningkatan yang berarti terhadap keterampilan metakognisi peserta didik kelas X MIPA 1 setelah diajar menggunakan model pembelajaran discovery learning berbantuan media flipbook.
\end{abstract}

Kata Kunci: Discovery learning, Flipbooks, Metakognisi.

\section{PENDAHULUAN}

Pendekatan pembelajaran yang lebih variatif dapat menjadikan proses pembelajaran lebih hidup. Salah satu mata pelajaran yang menuntut pembelajaran yang lebih variatif adalah fisika (Sari et al., 2021). Fisika memiliki peranan penting dalam meningkatkan mutu pendidikan yaitu untuk menghasilkan peserta didik yang berkualitas, di mana peserta didik mampu berpikir, kreatif, logis dan berinisiatif. Karena termasuk mata pelajaran yang tidak bisa ditransfer begitu saja dari pikiran guru ke peserta didik, sampai saat ini fisika masih dianggap sulit. Dari anggapan tersebut membuat peserta didik memberi respon yang kurang positif terhadap pembelajaran fisika, sehingga nantinya akan mempengaruhi ketuntasan belajar peserta didik.

Keberhasilan proses belajar mengajar selain ditentukan oleh metode pembelajaran, juga ditentukan oleh bagaimana peserta didik untuk mengelolah cara mereka menyelesaikan masalah atau tugas yang diberikan. Ada banyak jenis keterampilan yang seharusnya dimiliki oleh peserta didik agar hasil belajar yang diinginkan dapat tercapai, salah satunya yang dibutuhkan adalah keterampilan metakognisi. Keterampilan metakognisi dapat membantu peserta didik untuk mengetahui bagaimana cara mereka belajar, mengetahui kemampuan dan modalitas belajar yang dimiliki dan mengetahui strategi belajar terbaik untuk belajar efektif, keterampilan metakognisi yang berkembang dengan baik membuat peserta didik mampu menyadari kekuatan dan kelemahannya dalam belajar.

Keterampilan metakognisi menjadi perhatian peneliti karena seiring perkembangan zaman, kemampuan berpikir seperti ini sangat berperan dalam kegiatan belajar, (Wardana et al., 2020). Sejalan dengan penelitian yang dilakukan (Hamid, 2019) mengungkapkan bahwa pemberian masalah selama proses pembelajaran menuntut siswa untuk menggunakan keterampilan metakognisinya. Keterampilan metakognisi yang ideal bagi 
siswa yaitu tentang bagaimana cara memecahkan masalah, bagaimana perencanaan dalam memecahkan masalah, mengetahui alasan mengapa menggunakan cara tersebut, memonitor proses belajar saat melaksanakan rencana pemecahan masalah, serta mengevaluasi apa yang sudah dilakukan.

Salah satu sekolah yang menjadi perhatian bagi peneliti dalam aspek keterampilan metakognisi yang dianggap masih kurang adalah SMA Negeri 10 Gowa. Berdasarkan hasil observasi pada pembelajaran bidang studi fisika di kelas X SMA Negeri 10 Gowa, diperoleh informasi bahwa pengetahuan metakognisi masih kurang mendapatkan perhatian padahal berperan penting dalam menyelesaikan masalah pembelajaran. Ini ditunjukkan dengan hasil belajar peserta didik yang masih belum bisa dikatakan baik, karena peserta didik yang nilainya berada di bawah nilai KKM (75) masih berada di atas 50\%. Diketahui hanya sebanyak 12 orang dari 36 peserta didik yang memperoleh nilai di atas KKM, selain dari itu rata-rata nilai hanya berada di angka 51 .

Dalam hal ini, metode dan pendekatan yang digunakan masih belum dapat mengoptimalkan keterampilan metakognisi peserta didik. Metode yang dimaksud adalah metode konvensional (ceramah, tanya jawab dan pemberian tugas). Guru menyampaikan materi pelajaran berupa informasi yang harus didengar, dicatat, disimpan dan diujikan tanpa menggunakan bantuan media yang dapat meningkatkan perhatian siswa dalam pembelajaran. Penerapan metode pembelajaran tersebut cenderung membuat peserta didik pasif, bosan, malas belajar dan malas mengerjakan tugas. Peran guru sangat penting untuk menentukan metode yang paling tepat dengan langkah yang sistematis untuk dapat membangkitkan semangat belajar peserta didik (Hamid, 2019). $\mathrm{Hal}$ ini disebabkan karena dalam proses pembelajaran peserta didik tidak diberi kesempatan untuk melatih keterampilan metakognisinya. Selain itu dalam proses belajar mengajar kecenderungan guru tidak memanfaatkan media pemebalajaran sebagai sarana pendukung dalam memaksimalkan pembelajaran padahal sesungguhnya banyak media yang dapat dimanffatkan dalam pembelajaran saat ini (Putra, 2021), sehingga perlu adanya upaya yang dapat ditempuh untuk meningkatkan keterampilan tersebut, satu diantaranya adalah menggunakan model pembelajaran discovery learning yang berbantuan media flipbooks agar peserta didik bebas mengembangkan konsep yang mereka pelajari bukan hanya sebatas materi yang dicatat saja kemudian dihafal.

Model pembelajaran discovery learning ini dianggap cocok karena dapat melatih keterampilan kognitif peserta didik (Nurmala \& Priantari, 2017). Selanjutnya model ini mampu menagarahkan siswa dalam menemukan dan memecahkan masalah tanpa pertolongan orang lain, karena metode yang digunakan melatih peserta didik lebih banyak belajar sendiri. Kelebihan dari model discovery learning yang diungkapkan oleh (Hosnan, 2014) dalam model pembelajaran discovery learning ini, guru memberikan peserta didik persoalan yang harus dipecahkan, kemudian di akhir pembelajaran guru menjelaskan konsep baru berdasarkan pemecahan masalah yang ditemukan oleh peserta didik tersebut. Penelitian yang dilakukan oleh (Nurulhidayah et al., 2020) merekomendasikan bahwa dalam penerapan model pembelajaran discovery learning dalam mengajar idealnya menintegrasikan media pembelajaran yang menarik bagi siswa salatu media pembelajaran yang disarankan adalah media flipbooks. Menurut (Hayati et al., 2015) media pembelajaran flipbook yang digunakan dalam pembelajaran fisika dapat meningkatkan hasil belajar siswa. Berdasarkan latar belakang tersebut maka penelitian yang dilakukan ini mengambil topik Penerapan model discovery learning berbantuan media flipbooks dalam pembelajaran fisika untuk melatih keterampilan metakognisi peserta didik SMA Negeri 10 Kabupaten Gowa. Dalam penelitian ini diharapkan dapat mengetahui bagaimana peningkatan keterampilan metakognisi peserta didik sehingga para tenaga pendidik lebih menyadari pentingnya melatih keterampilan metakognisi peserta didik dalam kegiatan pembalajaran melalui model yang sesuai dan berbantuan media pemebalajaran.

\section{METODE}

Jenis penelitian yang digunakan adalah penelitian pra-eksperimen (Pre-Experimental Design). Desain penelitian yang digunakan adalah One-Group Pretest-Posttest Design. Pada desain ini, sebelum diberi perlakuan, maka terlebih dahulu sampel diberikan tes awal (pretest) dan di akhir pembelajaran sampel diberi tes akhir (posttest). One-Group Pretest-Posttet Design dinyatakan dengan pola (Sugiyono, 2017, p. 110). Populasi dalam penelitian ini adalah peserta didik kelas X yang ada di SMA Negeri 10 Gowa pada Semester Genap Tahun Ajaran 2020/2021 yang terdiri dari 2 (dua) kelas MIPA dengan jumlah peserta didik sebanyak 64 peserta didik. Sampel yang digunakan dalam penelitian ini yaitu kelas X MIPA 1 di SMA Negeri 10 Gowa yang berjumlah 34 peserta didik. Pengambilan sampel dilakukan dengan menggunakan teknik purposive sampling. Pemilihan metode purposive sampling didasari dari teknik pemilihan kelas yang ditentukan oleh guru dengan pertimbangan bahwa kelas X MIPA 1 memiliki respon terhadap pembelajaran yang lebih cepat dibandingkan kelas lainnya. Instrument 
Dalam penelitian ini menggunakan tes keterampilan metakognisi. Tes tersebut terdiri dari 9 (sembilan) soal esai dan dilakukan Pengujian validitas dan setiap butir soal instrument diuji reliabilitas diuji dengan menggunakan rumus alfa cronbach yang dikemukakan oleh (Sugiyono, 2019, p. 365). Kesembilan soal keterampilan metakognisi tersebut mencakup aspek planning (perencanaan), monitoring (pemantauan), dan evaluation (evaluasi) yang digunakan untuk mengukur keterampilan metakognisi (Safitri et al., 2020). Selanjutnya dilakukan uji Validitas Perangkat Pembelajaran yang terdiri dari Rencana Pelaksanaan Pembelajaran (RPP), bahan ajar, Lembar Kerja Peserta Didik (LKPD), dan tes keterampilan metakognisi. Validitas perangkat pembelajaran ini diuji menggunakan validitas konstruk dengan meminta pendapat para ahli. Dari hasil validitas oleh ahli tersebut selanjutnya dianalisis menggunakan uji gregory dengan tujuan untuk mengetahui jika istrumen tersebut layak untuk digunakan dalam penelitian. Uji gregory menurut (Retnawati, 2016, p.32). Data yang diperoleh diolah dengan mengggunakan teknik analisis deskriptif dan analisis inferensial.

\section{HASIL DAN PEMBAHASAN}

Hasil yang diperoleh dalam penelitian ini setalah dilakukan analisis deskriptif dan analisis inferensial, diperoleh bahwa terdapat peningkatan yang berarti terhadap keterampilan metakognisi peserta didik yang diajar dengan menggunakan model pembelajaran discovery learning berbantuan media flipbook pada kelas X MIPA 1 SMA Negeri 10 Gowa. Hasil yang diperoleh pada penelitian ini sesuai dengan beberapa penelitian sebelumnya diantaranya (Puspitasari \& Nurhayati, 2019) mengenai Pengaruh Model Pembelajaran Discovery Learning dengan Menggunakan Mediavideo dimana diperoleh peningkatan hasil belajar peserta didik berdasarkan perbandingan hasil pretest dan posttest $\mathrm{N}$-gain. Hal yang sama juga diperoleh oleh (Nafisa \& Wardono, 2019) dengan penelitian yang berjudul Model pembelajaran discovery learning berbantuan multimedia untuk meningkatkan kemampuan berpikir kritis siswa, dari hasil penelitian tersebut menunjukkan model pembelajaran discovery learning berbantuan multimedia mampu membangkitkan keaktifan siswa dalam proses pembelajaran, sehingga siswa terus bekerja hingga mencapai tujuan pembelajaran. Adapun gambaran hasil dari analisis yang telah dilakukan dalam penelitian ini adalah sebagai berikut.

\section{Analisis Deskriptif untuk skor Pretest}

Hasil analisis deskriptif pretest distribusi interval skor keterampilan metakognisi peserta didik dikategorisasikan dalam skala lima yaitu sangat tinggi, tinggi, sedang, rendah, dan sangat rendah keterampilan metakognisi peserta didik SMA Negeri 10 Gowa sebelum diajar menggunakan model discovery learning media flipbook pada materi usaha dan energi serta momentum dan impuls yang telah dikategorisasikan dapat dilihat pada Tabel 1.

Tabel 1. Distribusi Frekuensi dan Kategorisasi Skor Pretest

Keterampilan Metakognisi Peserta Didik

\begin{tabular}{ccc}
\hline Interval Skor & Kategori & Frekuensi \\
\hline $32-39$ & Sangat Tinggi & - \\
$24-31$ & Tinggi & 1 \\
$16-23$ & Sedang & 14 \\
$8-15$ & Rendah & 18 \\
$0-7$ & Sangat Rendah & 1 \\
\hline \multicolumn{3}{c}{ Jumlah } \\
\hline
\end{tabular}

Sumber: Data primer terolah (2021)

Dari Tabel 1 di atas diketahui bahwa pada rentang 32-39 tidak terdapat peserta didik yang memperoleh skor kategori sangat tinggi, pada rentang skor 24-31 terdapat 1 peserta didik yang memperoleh skor kategori tinggi, pada rentang skor 16-23 terdapat 14 peserta didik yang memperoleh skor kategori sedang, pada rentang skor 8-15 terdapat 18 peserta didik yang memperoleh skor kategori rendah, dan pada rentang skor 0-7 terdapat 1 peserta didik yang memperoleh skor kategori sangat rendah. Deskripsi table di atas menunjukkan bahwa frekuensi peserta didik paling banyak berada di kategori skor rendah, yaitu sebanyak 18 orang. Frekuensi peserta didik di urutan ke dua berada di kategori skor sedang, yaitu sebanyak 14 orang. Frekuensi peserta didik di urutan selanjutnya berada di kategori skor tinggi dan kategori skor rendah, masing-masing sebanyak 1 orang peserta didik. 
Selanjutnya Hasil tabulasi persentase skor rata-rata keterampilan metakognisi peserta didik tiap-tiap indikator dapat dilihat pada Tabel 2 berikut:

Tabel 2. Persentase Skor Rata-rata Pretest Keterampilan Metakognisi Peserta Didik Tiap Indikator

\begin{tabular}{cc}
\hline Indikator & Persentase (\%) \\
\hline Perencanaan & 37,75 \\
Pemantauan & 46,32 \\
Evaluasi & 35,78 \\
\hline
\end{tabular}

Sumber: Data primer terolah (2021)

Dari Tabel 2 di atas dapat diketahui bahwa pada indikator perencanaan, persentase skor rata-rata peserta didik diperoleh sebesar 37,75\%, pada indikator pemantauan persentase skor rata-rata peserta didik diperoleh sebesar 46,32\%, dan pada indikator evaluasi persentase skor rata-rata peserta didik diperoleh sebesar 35,78\%. Deskripsi table tersebut menunjukkan bahwa persentase skor rata- rata pretest paling tinggi berada pada indikator pemantauan, setelah itu diikuti indikator perencanaan, dan kemudian indikator evaluasi.

\section{Analisis Deskriptif untuk skor Posttest}

Hasil analisis deskriptif posttest distribusi pada interval skor keterampilan metakognisi peserta didik dikategorisasikan dalam skala lima yaitu sangat tinggi, tinggi, sedang, rendah, dan sangat rendah keterampilan metakognisi peserta didik SMA Negeri 10 Gowa setelah diajar menggunakan model discovery learning berbantuan media flipbook pada materi usaha dan energi serta momentum dan impuls yang telah dikategorisasikan dapat dilihat pada Tabel 3 berikut

Tabel 3. Distribusi Frekuensi dan Kategorisasi Skor Posttest Keterampilan Metakognisi Peserta Didik

\begin{tabular}{ccc}
\hline Interval Skor & Kategori & Frekuensi \\
\hline $32-39$ & Sangat Tinggi & 5 \\
$24-31$ & Tinggi & 20 \\
$16-23$ & Sedang & 9 \\
$8-15$ & Rendah & - \\
$0-7$ & Sangat Rendah & - \\
\hline \multicolumn{2}{c}{ Jumlah } & 34 \\
\hline
\end{tabular}

Sumber: Data primer terolah (2021)

Dari Tabel 3 di atas diketahui bahwa pada rentang 32-39 terdapat 5 peserta didik yang memperoleh skor kategori sangat tinggi, pada rentang skor 24-31 terdapat 20 peserta didik yang memperoleh skor kategori tinggi, pada rentang skor 16-23 terdapat 9 peserta didik yang memperoleh skor kategori sedang, pada rentang skor 8-15 tidak terdapat peserta didik yang memperoleh skor kategori rendah, dan pada rentang skor $0-7$ tidak terdapat peserta didik yang memperoleh skor kategori sangat rendah. Deskripsi table tersebut menunjukkan bahwa frekuensi peserta didik paling banyak berada di kategori skor tinggi, yaitu sebanyak 20 orang. Frekuensi peserta didik di urutan ke dua berada di kategori skor sedang, yaitu sebanyak 9 orang. Frekuensi peserta didik di urutan selanjutnya berada di kategori skor tinggi, yaitu sebanyak 5 orang.

Selanjutnya hasil tabulasi persentase skor rata-rata keterampilan metakognisi peserta didik tiap-tiap indikator dapat dilihat pada Tabel 4.

Tabel 4. Persentase Skor Rata-rata Pretest Keterampilan Metakognisi Peserta Didik Tiap Indikator

\begin{tabular}{cc}
\hline Indikator & Persentase (\%) \\
\hline Perencanaan & 84,17 \\
Pemantauan & 71,67 \\
Evaluasi & 62,50 \\
\hline
\end{tabular}

Sumber: Data primer terolah (2021)

Dari Tabel 4 di atas dapat diketahui bahwa pada indikator perencanaan, persentase skor rata-rata peserta didik diperoleh sebesar $84,17 \%$, pada indikator pemantauan persentase skor rata-rata peserta didik diperoleh sebesar $71,67 \%$, dan pada indikator evaluasi persentase skor rata-rata peserta didik diperoleh sebesar 62,50\%. 
Deskripsi persentase skor rata- rata posttest paling tinggi berada pada indikator perencanaan, setelah itu diikuti indikator pemantauan, dan kemudian indikator evaluasi.

Berdasarkan analisis deskriptif keterampilan metakognisi peserta didik yang telah dilakukan, menunjukkan bahwa persentase skor rata-rata pretest paling tinggi berada pada indikator pemantauan, setelah itu diikuti indikator perencanaan, dan kemudian indikator evaluasi. Sedangkan persentase skor rata-rata posttest paling tinggi berada pada indikator perencanaan, setelah itu diikuti indikator pemantauan, dan kemudian indikator evaluasi. Adanya peningkatan skor rata-rata pada tiap indikator menunjukkan bahwa peserta didik sudah mulai mampu untuk mengelolah cara mereka berpikir, yaitu dalam hal membuat perencanaan, menggunakan data yang ada untuk menyelesaikan masalah, dan mengevaluasi apa yang telah dilakukan.

\section{Analisis Inferensial atau pengujian Hipotesis}

Setelah hasil pengujian data skor pretest dan posttest membuktikan bahwa data terdistribusi normal, maka selanjutnya data tersebut dapat digunakan untuk pengujian hipotesis. Uji hipotesis merupakan jenis pengujian statistik untuk mengetahui apakah terdapat perbedaan keterampilan metakognisi peserta didik sebelum diajar menggunakan model discovery learning berbantuan media flipbook dengan keterampilan metakognisi peserta didik setelah diajar menggunakan model discovery learning berbantuan media flipbook.

Pengujian hipotesis yang digunakan adalah uji dua pihak dengan kriteria pengujian Hipotesis nol $\left(\mathrm{H}_{0}\right)$ diterima bilamana $t_{\text {hitung }}<\mathrm{t}(1-\alpha)(\mathrm{dk})$ di mana $\mathrm{t}(1-\alpha)$ diperoleh dari daftar distribusi $\mathrm{t}$ dengan taraf signifikan $\alpha=0,05$. Untuk $\mathrm{H}_{1}$ diterima bilamana thitung $>\mathrm{t}(1-\alpha)(\mathrm{dk})$ dengan menentukan $\mathrm{dk}=\mathrm{n}_{1}+\mathrm{n}_{2}-2$ taraf signifikan $\alpha=5 \%$ dan peluang (1- $\alpha)$. Berdasarkan hasil pengujian hipotesis penelitian dengan menggunakan uji-t, untuk nilai $t_{\text {hitung }}$ sebesar 8,9424 sedangkan $t_{\text {tabel }}$ sebesar 2,036. Hasil yang diperoleh menunjukkan bahwa $t_{\text {hitung }}>t_{\text {tabel }} \quad$ yang artinya $\mathrm{H}_{0}$ ditolak dan $\mathrm{H}_{1}$ diterima, hal ini menunjukkan bahwa terdapat peningkatan yang berarti terhadap keterampilan metakognisi peserta didik kelas X MIPA 1 setelah diajar menggunakan model pembelajaran discovery learning berbantuan media flipbook.

Berdasarkan hal tersebut dapat digambarkan bahwa metakognisi merupakan daya pikir dalam menyelesaikan masalah atau soal-soal sehingga peserta didik mampu mengetahui seberapa besar kesalahan atau kebenaran dalam menyelesaikan masalah. Sejalan dengan penelitian (Rahman, 2018) yang menungkapkan bahwa dengan keterampilan metakognisi dapat membantu peserta didik untuk memahami bagaimana mengerjakan tugas dengan baik dan membantu pengelolaan belajar pada perencanaan, pemantauan aktivitas kognitif, dan mengevaluasi hasilnya. Pembelajaran dengan model discovery learning atau teknik penemuan akan membantu peserta didik untuk dapat menemukan konsep-konsep dan prinsip-prinsip melalui proses mentalnya sendiri (Putri et al., 2017). Model discovery learning berbantuan media flipbook dalam penelitian ini melatih keterampilan-keterampilan kognitif peserta didik untuk menemukan dan memecahkan masalah serta melatih peserta didik lebih banyak belajar secara mandiri.

\section{SIMPULAN}

Berdasarkan hasil analisis data dan pembahasan maka kesimpulan dari penelitian ini menunjukkan keterampilan metakognisi peserta didik kelas X MIPA 1 SMA Negeri 10 Gowa setelah diajar menggunakan model pembelajaran discovery learning dengan media flipbook memperoleh skor rata-rata sebesar 26,12 meningkat dibanding skor sebelumnya yang hanya rata-rata sebesar 14,38. Hal ini menunjukkan keterampilan metakognisi peserta didik setelah diajar menggunakan pembelajaran discovery learning berbantuan media flipbook lebih tinggi dibandingkan sebelum diajar menggunakan pembelajaran discovery learning dengan media flipbook.

\section{Ucapan Terima Kasih}

Ucapan terima kasih kami sampaikan pada kepala SMA Negeri 10 Gowa dan guru pendidikan fisika yang telah memfasilitasi dan mengizinkan kami untuk melakukan penelitian, kepada pembimbing bapak Dian Pramana Putra, M.Pd yang dengan sabar membimbing penulis sampai selesai dan semua pihak yang telah membantu. 


\section{Daftar Pustaka}

Hamid, A. (2019). Berbagai Metode Mengajar bagi Guru dalam Proses Pembelajaran. Jurnal Penelitian Sosial Dan Keagamaan, 9(2), 1-16. http://www.ejournal.annadwah.ac.id/index.php/aktualita/article/download/97/72

Hayati, S., Budi, A. S., \& Handoko, E. (2015). Pengembangan Media Pembelajaran Flipbook Fisika untuk Meningkatkan Hasil Belajar Peserta Didik. Prosiding Seminar Nasional Fisika (e-Jurnal) SNF2015, IV, 49-54.

Hosnan. (2014). Pendekatan Saintifik dan Kontekstual dalam Pembelajaran Abad 21. Jakarta: Ghalia Indonesia.

Nafisa, D., \& Wardono. (2019). Model Pembelajaran Discovery Learning Berbantuan Multimedia Untuk Meningkatkan Kemampuan Berpikir Kritis Siswa. Prisma, 2, 854-861.

Nurmala, R. S., \& Priantari, I. (2017). Meningkatkan Keterampilan Komunikasi Discovery Learning Improving Communication Skills And Cognitive Study Result Through Discovery. Jurnal Biologi Dan Pembelajaran Biologi, 2(1), 1-10. http://jurnal.unmuhjember.ac.id/index.php/BIOMA/article/view/586

Nurulhidayah, M. R., Lubis, P. H. M., \& Ali, M. (2020). PENGARUH MODEL PEMBELAJARAN DISCOVERY LEARNING MENGGUNAKAN MEDIA SIMULASI PhET TERHADAP PEMAHAMAN KONSEP FISIKA SISWA. Jurnal Pendidikan Fisika, 8(1), 95. https://doi.org/10.24127/jpf.v8i1.2461

Puspitasari, Y., \& Nurhayati, S. (2019). Pengaruh Model Pembelajaran Discovery Learning Terhadap Hasil Belajar Siswa. Jurnal Pendidikan Dan Kewirausahaan, 7(1), 93-108. https://doi.org/10.47668/pkwu.v7i1.20

Putra, D. P. (2021). Pengembangan Media Pembelajaran Fisika Menggunakan Kartun 3D. Jurnal Literasi Digital, $1(2), 88-93$.

Putri, R. H., Lesmono, A. D., \& Aristya, P. D. (2017). Pengaruh Model Discovery Learning Terhadap Motivasi Belajar Dan Hasil Belajar Fisika Siswa MAN Bondowoso. Jurnal Pembelajaran Fisika, 6(2), 168-174.

Rahman, A. (2018). Profil Kemampuan Berpikir Kritis Dan Kemampuan Metakognitif Siswa Berdasarkan Jenis Kelamin. Jurnal Pendidikan Biologi, 10(1), 28. https://doi.org/10.17977/um052v10i1p28-43

Retnawati, Heri. 2016. Analisis Kuantitatif Instrumen Penelitian. Yogyakarta: Parama Publishing

Safitri, P. T., Yasintasari, E., Putri, S. A., \& Hasanah, U. (2020). Analisis Kemampuan Metakognisi Siswa dalam Memecahkan Masalah Matematika Model PISA. Journal of Medives : Journal of Mathematics Education IKIP Veteran Semarang, 4(1), 11. https://doi.org/10.31331/medivesveteran.v4i1.941

Sari, P., Dwikoranto, D., \& Lestari, N. A. (2021). Analisis Respon dan Ketertarikan Peserta Didik Terhadap Pelaksanaan Pembelajaran Fisika Berbasis Environmental Learning di SMA. PENDIPA Journal of Science Education, 5(3), 337-344. https://doi.org/10.33369/pendipa.5.3.337-344

Sugiyono. 2017. Metode Penelitian Kuantitatif, Kualitatif dan REDD. Bandung: Alfabeta.

Sugiyono. 2019. Statistika untuk Penelitian. Bandung: Alfabeta.

Wardana, R. W., Prihatini, A., \& Hidayat, M. (2020). Identifikasi Kesadaran Metakognitif Peserta Didik dalam Pembelajaran Fisika. PENDIPA Journal of Science Education, 5(1), 1-9. https://doi.org/10.33369/pendipa.5.1.1-9 